\title{
University Ecosystems and the Commitment of Faculty Members to Support Entrepreneurial Activity
}

Gustavo Hermínio Salati Marcondes de Moraes ${ }^{1}$

Bruno Brandão Fischer ${ }^{1,2}$

Matheus Leite Campos ${ }^{1}$

Paola Rücker Schaeffer ${ }^{1}$

${ }^{1}$ Universidade Estadual de Campinas, Campinas, SP, Brazil ${ }^{2}$ National Research University Higher School of Economics, Moscow, Russia

Received 28 January 2019. This paper was with the authors for two revisions. Accepted 8 April 2020. First published online 7 May 2020.

Alexandre Nabil Ghobril was the associate editor for this article.

Editor-in-chief: Carlo Gabriel Porto Bellini

Editorial assistant: Luciane Kato Kiwara 


\begin{abstract}
Research on the concept of entrepreneurial universities has dedicated significant attention to understand how academic ecosystems shape the propensity of its members to establish new ventures. In this article we look at a prior step of the entrepreneurial event, i.e., how universities' dynamics and initiatives related to entrepreneurship affect the proclivity of faculty to engage in entrepreneurship support. We propose and validate a conceptual model that directly relates the university ecosystem with faculty engagement, having entrepreneurial experience of faculty as a moderator and analyzing differences between public and private institutions. Data comprises information from 680 faculty members of over 70 higher education institutions from all regions of Brazil. Analyses were performed using Partial Least Squares Structural Equations Modeling. Results point to a strong positive relation between developed university ecosystems and the engagement of faculty with entrepreneurial activities, especially for individuals with stronger entrepreneurial experience. No differences were found between private and public institutions. From a practical standpoint, it is possible to identify more effective, innovative, and systematic ways to implement intrapreneurial practices in universities.
\end{abstract}

Keywords: universities; academic entrepreneurship; Brazil; entrepreneurial culture.

JEL code: M13 


\section{Introduction}

Over the last two decades, universities have seen a progressive inclusion of the third mission in their strategic orientation - in addition to teaching and research - with particular emphasis on innovation and economic development (Audretsch, 2007; Goldstein, 2010). The main goal behind this rationale is to further integrate academia and productive systems, making universities more economically engaged institutions (Etzkowitz \& Leydesdorff, 2000; Rasmussen, Moen, \& Gulbrandsen, 2006). In this regard, a key mode of technology transfer consists in the capacity of academia to generate spin offs with high innovative potential and the respective socioeconomic impacts that follow (Audretsch, Grilo, \& Thurik, 2011; Bercovitz \& Feldman, 2006; Ferreira, Fayolle, Fernandes, \& Raposo, 2017). The university itself can be perceived as a natural incubator of these new ventures, provided it can offer an adequate atmosphere for students to explore and exploit new ideas (Kirby, Urbano, \& Guerrero, 2011).

Following this perspective, many universities have established initiatives to foster ecosystems that are conducive to entrepreneurial activity in students and academics (Galán-Muros, Sijde, Groenewegen, \& Baaken, 2017; Guerrero, Urbano, \& Fayolle, 2016; Peterman \& Kennedy, 2003). Accordingly, researchers have been dedicating attention to strategies that aim at positioning universities as entrepreneurial hubs (Gnyawali \& Fogel, 1994; Siegel \& Wright, 2015). Such strategic approaches are linked to the principles of corporate entrepreneurship (or intrapreneurship), in which the university stands for an organizational context with particular specificities (Brennan, Wall, \& McGowan, 2005; Kirby, 2006; Liu \& Dubinsky, 2000; Woollard, 2010)

An aspect of interest in this realm concerns the entrepreneurial ecosystems embedded in higher education institutions (Miller \& Ács, 2017) and their respective relationship with corporate strategy (Braunerhjelm, 2007; Kirby, 2006; Woollard, 2010). Along these lines, Kalar and Antonic (2015) propose that the entrepreneurial university - and its respective corporate entrepreneurship strategy - requires fostering a culture of innovation that encourages individuals to pursue knowledge dissemination through new channels. In fact, matters associated with entrepreneurship-friendly cultures, policies, and practices lie at the heart of the concept of entrepreneurial universities (Bercovitz \& Feldman, 2004; Clark, 1998; Huyghe \& Knockaert, 2015; Kirby, 2006; Meyers \& Pruthi, 2011; Siegel, Waldman, \& Link, 2003). This perspective puts emphasis on intrapreneurship driving elements such as internal (organizational structure and support systems) and strategic (mission, vision, and reward systems) factors as a means to leverage capabilities in higher education institutions (Markuerkiaga, Errasti, \& Igartua, 2014). Nonetheless, literature in the field has dedicated scant attention to such cultural aspects, a function of the difficulty in addressing informal settings - particularly from a quantitative point of view.

To help filling this gap, this research deviates from the traditional focus on the entrepreneurial event itself (i.e., new firm formation) to look into the contextual determinants of faculty engagement as a vector of corporate entrepreneurship in these processes. As Wadhwani, GalvezBehar, Mercelis and Guagnini (2017) argue, the concept of academic entrepreneurship can have

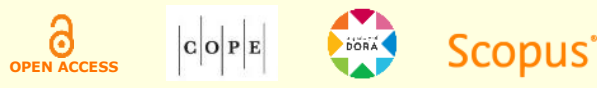


different meanings that go beyond the narrow focus on research commercialization. Accordingly, we look at faculty members as potential intrapreneurs, i.e., agents responsible for creating platforms that guide social change, enabling behavioral shifts in other individuals by modifying the underlying settings concerning entrepreneurial incentives (Chiles, Bluedorn, \& Gupta, 2007; Clark, 1998; Gurãu, Dana, \& Lasch, 2012; Mars \& Rios-Aguilar, 2010).

Bearing this context in mind, the goal of this research is to evaluate whether the university ecosystem influences the engagement of faculty in supporting entrepreneurial activities and education at the institutional level. This goal is in tandem with the idea that effective corporate entrepreneurship relies on the connection of high-level strategies at the organizational level with the implementation of a culture that fosters entrepreneurial commitment among academics and students (Ireland, Covin, \& Kuratko, 2009; Kirby, 2006).

It is noteworthy that the literature on this topic has provided scant insights on (a) the antecedents of intrapreneurship in universities (Farrukh, Lee, \& Shahzad, 2019) and on (b) the microfoundations of universities' third mission regarding faculty members' engagement (Freel, Persaud, \& Chamberlin, 2019). To cover this gap, we concentrate our attention on the connections between formal corporate initiatives of universities to develop functional entrepreneurial ecosystems and their impacts on faculty engagement with promoting an entrepreneurial culture within the institution. Ultimately, these relationships represent a relevant asset in triggering intrapreneurial behavior and a culture for entrepreneurship within universities' ecosystems.

Our empirical approach is based on data from 680 faculty members of 70 Higher Education Institutions (HEIs) located across 22 states in Brazil. The dataset was developed in 2016 by Endeavor and Brazilian Micro and Small Business Support Service (Serviço Brasileiro de Apoio às Micro e Pequenas Empresas [Sebrae]) and made available to the authors for the purposes of this assessment. The Brazilian context makes for an interesting analytical case. On the one hand, universities in this country have sought adequate configurations to uphold entrepreneurship by implementing institutional mechanisms that lend support to the creation of new ventures and the education of entrepreneurs (Perlatto, 2013). Notwithstanding, the effectiveness of these initiatives in terms of new firm creation is disappointing (Alves, Fischer, Schaeffer, \& Queiroz, 2019). Therefore, our comprehension of the dynamics of corporate entrepreneurship leading to entrepreneurial universities in Brazilian higher education institutions remains limited.

Results are derived from estimations using Structural Equation Modeling with Partial Least Squares (PLS-SEM). Findings indicate an association between universities' ecosystems and the commitment of faculty members to support entrepreneurial activity. Furthermore, the entrepreneurial experience of faculty moderates this relationship, in which the connection between universities' ecosystems and academics' commitment to entrepreneurship promotion is stronger in those professors who are more closely involved with entrepreneurship as a professional practice. Furthermore, no differences were found for the comparison between public and private institutions.

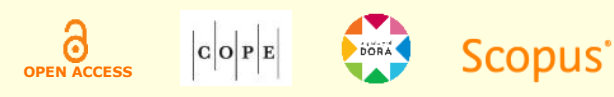


These outcomes represent novel evidence on the dynamics of entrepreneurial ecosystems of academic institutions and they suggest an association between formal practices and shifts in faculty behavior (an informal output of the process). Thus, our research contributes to the discussion on the formation of universities' ecosystems and the ways through which they might reinforce themselves over time by strengthening faculty engagement with the entrepreneurial event. From a theoretical point of view, the apparent inefficiency of corporate strategies in driving entrepreneurial activity in students may be due to inadequate timing of appraisals, since evolutionary processes that involve deeper changes - and have longer maturation periods - can be at play (a typical ecosystem feature).

The article is structured as follows. After these introductory arguments, second section articulates the literature on entrepreneurial universities, the role of faculty, and the relevance of institutional settings of universities' ecosystems. We also discuss additional perceptions on potential moderating effects of faculty entrepreneurial experience and differences between public and private institutions. From this literature, we derive our guiding hypotheses. Third section presents the conceptual model and the analytical method. Fourth section reports the empirical results, which are discussed in fifth section. Sixth section concludes with final remarks, implications, and avenues for future research.

\section{Corporate Strategy and the Emergence of Entrepreneurial Universities}

Although the concept of entrepreneurial universities has been coined in the 1980s (Etzkowitz, 1983), the underlying notion of closer approximation between academia and markets dates back to the nineteenth century. Since then, academics have been involved in activities that aim at translating research into technological development, generation of new business, as well as inspiring change in social and governmental practices (Wadhwani, Galvez-Behar, Mercelis, \& Guagnini, 2017). Nonetheless, it was not until the last two decades that practices related to such activities became entrenched in the mentality of decision makers (Audretsch, 2007; Rubens, Spigarelli, Cavicchi, \& Rinaldi, 2017).

In order for universities to match the organizational needs to adapt to this changing context, they must become more entrepreneurial themselves, thus fostering practices of intrapreneurship (Farrukh et al., 2019). Accordingly, prior literature suggests that the view of corporate entrepreneurship practices offers a suitable lens to address how a closer connection between higher education institutions and markets can be established (Vorley \& Nelles, 2010). With this in mind, the entrepreneurial university concept should not be taken as given since it requires active engagement of academic institutions with this process.

In fact, most universities have not been involved with changes in organizational structure and governance, hindering their capacity of becoming effectively entrepreneurial (Dovey \& Rembach, 2015). In order to turn the entrepreneurial university concept into an operational scheme, many challenges are posed, which go far beyond simply stating strategic goals (Di Gregorio \& Shane, 2003). Instead, this is a context in which institutional innovations and initiatives undertaken at the level of higher education institutions are required in order to have the expected pervasive

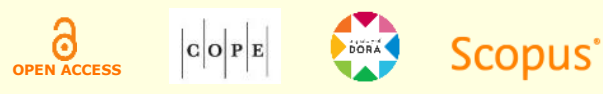


effects on the dynamics of entrepreneurship arising from academic contexts (Mars \& RiosAguilar, 2010).

Approaches from corporate entrepreneurship literature involve a number of elements that encompass top management's entrepreneurial strategic vision and organizational architectures that foster intrapreneurial behavior (Ireland et al., 2009). Accordingly, in order to become entrepreneurial, universities require a corporate strategy that addresses institutional intents towards entrepreneurship, internal policies that provide knowledge and support for entrepreneurial endeavors, and an environment that reduces risks involved in these processes (Kirby, 2006; Woollard, 2010). These features are also supported by Markuerkiaga, Errasti and Igartua (2014), who refer to internal (organizational structure and support) and strategic factors (mission, vision, and reward systems). In turn, such conditions are associated with the propensity of faculty to engage in the entrepreneurial university concept and assist the promotion of an entrepreneurial culture.

\section{Intrapreneurship in universities I: The role of faculty}

A fundamental aspect in implementing corporate entrepreneurship in academic settings and the resulting emergence of entrepreneurial universities concerns the capacity of these organizations to adapt their structures and methods to reduce asymmetries with the ecosystems in which they participate, fostering a stronger entrepreneurial orientation in their staff, faculty, and students (Belitski \& Heron, 2017). However, these dynamics are not independent from the people involved in this context of change. Rather, the genesis of an entrepreneurial culture within academic settings lies on the actions of those same individuals who shape the conditions for opportunity identification, resource allocation, and legitimization of the act of starting a new venture (Wadhwani et al., 2017). Here, the role played by faculty members is crucial in putting in motion an entrepreneurial multiplier effect within their respective HEIs (Galambos \& Amatori, 2016; Rubens et al., 2017).

In this regard, literature has recently identified a knowledge gap in terms of the relationship between the intrapreneurial academics (those who foster cultural change within an institution) and the process of universities becoming entrepreneurial (Rae, Gee, \& Moon, 2009). What had been observed so far is the importance of championing individuals who feed their contexts with meaning and energy to the entrepreneurial process so as to generate an atmosphere conducive to entrepreneurship (Beyhan \& Findik, 2018; Guerrero et al., 2016; Rao \& Mulloth, 2017).

Hence, the role of these champions in linking corporate-level strategies to daily routines becomes key in establishing an entrepreneurial culture in academic institutions (Clark, 1998; Coyle, 2014; Göktepe-Hultén, 2008; Vaziri, Safari, \& Akbarpur, 2013; Woollard, 2010). In addition, these individuals can alter the prevailing social norms in the academic settings (Krueger, Reilly, \& Carsrud, 2000) and legitimize entrepreneurship as a valid academic path (Bercovitz \& Feldman, 2008; Rasmussen \& Borch, 2010). This is a main challenge in a context where resistance and criticism concerning the implementation of initiatives related to entrepreneurship are still substantial (Bienkowska \& Klofsten, 2012).

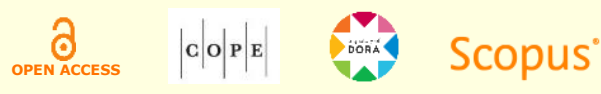


Along this line, faculty can establish supportive behaviors for organizational change (WhelanBerry, Gordon, \& Hinings, 2003). Their behavior inside and outside the classroom has the ability to promote social learning and cultural changes, creating an ecosystem conducive to entrepreneurial activity in students (Bercovitz \& Feldman, 2008; Bienkowska \& Klofsten, 2012; Boh, De-Haan, \& Strom, 2016). These cultural changes represent a key aspect of the supportive approach of universities towards the generation of spin offs (O'Shea, Allen, Morse, O'Gorman, $\&$ Roche, 2007). In fact, there is a strong complementarity among these levels, since without direct support from influential individuals, larger initiatives from the university are likely to be ineffective (Bienkowska, Klofsten, \& Rasmussen, 2016).

\section{Intrapreneurship in universities II: Organizational ecosystems}

Even though the abovementioned role of faculty members in setting an entrepreneurial culture in universities is deemed key in the intrapreneurial process, we must address the fact that individuals' behavior is embedded in organizational settings that shape their behavior. Accordingly, entrepreneurial universities rely heavily on institutional ecosystems that offer support and acceptation of entrepreneurship as a legitimate activity, making it part of the organizational culture (Nasution, Mavondo, Matanda, \& Ndubisi, 2011).

The usual framework to address entrepreneurial ecosystems posits that such socioeconomic structures are fundamentally represented by the linkages between economic agents and institutions, as well as their respective governance structures (Mason \& Brown, 2014). Universities have been traditionally inserted in this context as an element of entrepreneurial ecosystems (Isenberg, 2010). Nonetheless, recent literature has understood the university as an ecosystem in its own merit (e.g., Miller \& Ács, 2017; Morris, Shirokova, \& Tsukanova, 2017). Following this line of thinking, the University Ecosystem is composed by the availability of assets and infrastructure within campus, curricular programming, leadership, and shared values and norms (Rideout \& Gray, 2013).

These components mainly include entrepreneurship education, entrepreneurial teaching methodologies, support measures for entrepreneurship (such as incubators, science parks, entrepreneurship centers, etc.), staff development in entrepreneurship, and role models, among other elements (Markuerkiaga et al., 2014). Following this argument, activities that happen inside or outside the classroom, but are embedded in the university ecosystem, can be drivers for entrepreneurial activity (Fayolle \& Liñán, 2014; Marzocchi, Kitagawa, \& Sánchez-Barrioluengo, 2019; Moraes, Iizuka, \& Pedro, 2018). Indeed, as part of the university, the faculty members are also affected and stimulated by the academic ecosystem in which they exert their professional undertakings (Ruskovaara, Hämäläinen, \& Pihkala, 2016). This brings to the fore the need for an active interplay between individual actions and the framework of incentives offered by the institution (O'Shea et al., 2007).

However, there is a distinct barrier to entrepreneurship within universities (Rasmussen, Mosey, \& Wright, 2014), leading HEIs to demonstrate heterogeneous entrepreneurial propensities (Di

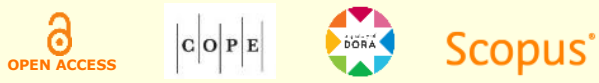


Gregorio \& Shane, 2003; Huyghe \& Knockaert, 2015). On many occasions, the lacking element for universities is an adequate institutional configuration and culture to be able to foment its entrepreneurs (Ács, Braunerhjelm, Audretsch, \& Carlsson, 2009). Resultantly, academic institutions often fail to provide institutional support or incentives for faculty to engage in actions related to entrepreneurship (Piperopoulos, 2012).

Therefore, entrepreneurship-friendly practices (e.g., institutional partnerships, structures for the elaboration and provision of content, support to research and training programs) become necessary for the university ecosystem to thrive (Bercovitz \& Feldman, 2004; Huyghe \& Knockaert, 2015). A university that truly desires to stimulate entrepreneurial behavior requires organizational structures that are able to increase the connection between teaching, research, entrepreneurial, and management activities (Guerrero \& Urbano, 2012; Marzocchi et al., 2019). However, as previously outlined, the university ecosystem is also composed by leadership and shared norms and values. In this regard, the role of faculty as an enabler of an entrepreneurial culture is a critical feature of functional ecosystems - although an often-forgotten dimension in this field of research (Freel et al., 2019). By considering the influence of the university ecosystem and the importance of the role played by faculty in supporting entrepreneurship, we propose the primary hypothesis of our research:

H1: Entrepreneurship-friendly university ecosystems have a positive influence on the commitment of faculty members to support entrepreneurial activities.

\section{The moderating role of faculty entrepreneurial experience}

From the student's perspective, educational practices and the work experience of faculty, especially entrepreneurial experience, are perceived as responsible for the promotion and development of personal changes (attitude, knowledge, ability, and entrepreneurial intention), also giving support for starting new companies (Mars, 2007; Nabi, Liñán, Fayolle, Krueger, \& Walmsley, 2017; Othman, Hashim, \& Wahid, 2012; Stadler \& Smith, 2017). In this regard, there is an open debate regarding the impact of previous experience of faculty on engaging in entrepreneurial activities (Hindle, 2007). Recent studies indicate that professors with work experience in industrial activities are more committed to entrepreneurial initiatives in general (Abreu \& Grinevich, 2013; Gulbrandsen \& Thune, 2017; Lubango \& Pouris, 2007; Moutinho, Fontes, \& Godinho, 2007; Novotny, 2017). Furthermore, some authors support the notion that faculty with prior experience in launching new ventures are valued in entrepreneurial education, given their ability to bring real examples to the classroom, as well as enthusiasm for teaching the topic and engaging to use innovative methods (Diegoli, Gutierrez, \& Salmones, 2018; Hopkins \& Feldman, 1989; Stadler \& Smith, 2017).

Regarding networks, non-academic experiences reduce cognitive and relational distances between academics and their business counterparts, resulting in strengthened network ties, improved social capital, and providing access to knowledge gatekeepers (Abaho, Olomi, \& Urassa, 2015; Bennett, 2006; Dietz \& Bozeman, 2005; Rossano-Rivero \& Wakkee, 2019; Ruskovaara, Pihkala,

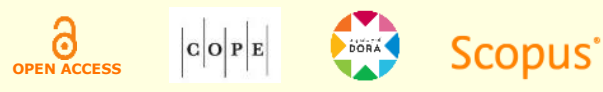


Sikkula-Leino, \& Järvinen, 2015). Also, the importance of entrepreneurial faculty members is not only restricted to those who teach entrepreneurship courses, but also to professors who have their own businesses and teach other subjects, given their ability to empirically demonstrate the application of theories in the classroom (Feldman, 2014). As a result, these professors become role models and play an important part in students' learning process (Feldman, 2014; Lashley \& Barron, 2006).

Part of this commitment to entrepreneurial education is related to entrepreneurs' beliefs regarding their responsibility of putting something back into the entrepreneurial ecosystem that supports their activities (Hopkins \& Feldman, 1989). In this sense, our second research hypothesis addresses the moderating impact of faculty entrepreneurial experience on the commitment to support entrepreneurial activities within universities' ecosystems.

H2: Entrepreneurial experience of faculty moderates the impact of universities' ecosystems on the commitment of faculty to support entrepreneurial activities.

\section{Organizational differences in public vs. private universities}

While universities can establish corporate strategies to foster intrapreneurial behavior and achieve the status of entrepreneurial institutions, barriers do exist and are more noticeable in public institutions (Kirby, 2006). For the national context of this research (Brazil), such differences arise due to structural differences concerning the organizational environments of public and private universities (Barral, Ribeiro, \& Canever, 2018; Canever, Barral, \& Ribeiro, 2017; Rowe \& Bastos, 2010).

These distinctions are mainly attributed to two aspects. First, faculty in public universities is primarily engaged in scientific research (Barral et al., 2018; Rowe \& Bastos, 2010; Speller, Robl, $\&$ Meneghel, 2012). This makes the public university environment more oriented to the academic career and scientific production, which may indicate a feeble relation with incentives to entrepreneurship (Ipiranga, Freitas, \& Paiva, 2010). Second, regulatory frameworks that deal with public universities' connections with market agents in Brazil pose significant barriers for an approximation between these higher education institutions and the broader entrepreneurial ecosystem (Alves et al., 2019; Fischer, Moraes, \& Schaeffer, 2019). As a consequence, institutional adaptation towards more entrepreneurial modes of operation is hindered (Fischer et al., 2019).

On the other hand, private universities show higher levels of interaction with the market environment (Andrade, 2012; Barral et al., 2018). In addition, evidence from the United States highlights that private universities possess distinctive strengths in terms of developing support infrastructures for entrepreneurship (Powers \& McDougall, 2005). Taking these potential differences into account, our third hypothesis can be stated as follows: 
H3: In a comparison with public institutions, private universities present stronger relationships between their academic ecosystems and the commitment of faculty members to support entrepreneurial activities.

\section{Conceptual Model and Analytical Method}

This research was conducted using a quantitative methodology, with the use of multivariate data analysis. Since the objectives are to predict and explain the presented constructs, and since the model presents formative constructs, in accordance with suggestions by Hair, Hult, Ringle and Sarstedt (2017), we used Structural Equation Modeling with the Partial Least Squares (PLS-SEM) technique. From the literature review and formulation of the hypotheses, a model was elaborated to meet the research purpose (Figure 1), aiming at understanding the effects of universities' ecosystems on the commitment of faculty to support entrepreneurial activities.

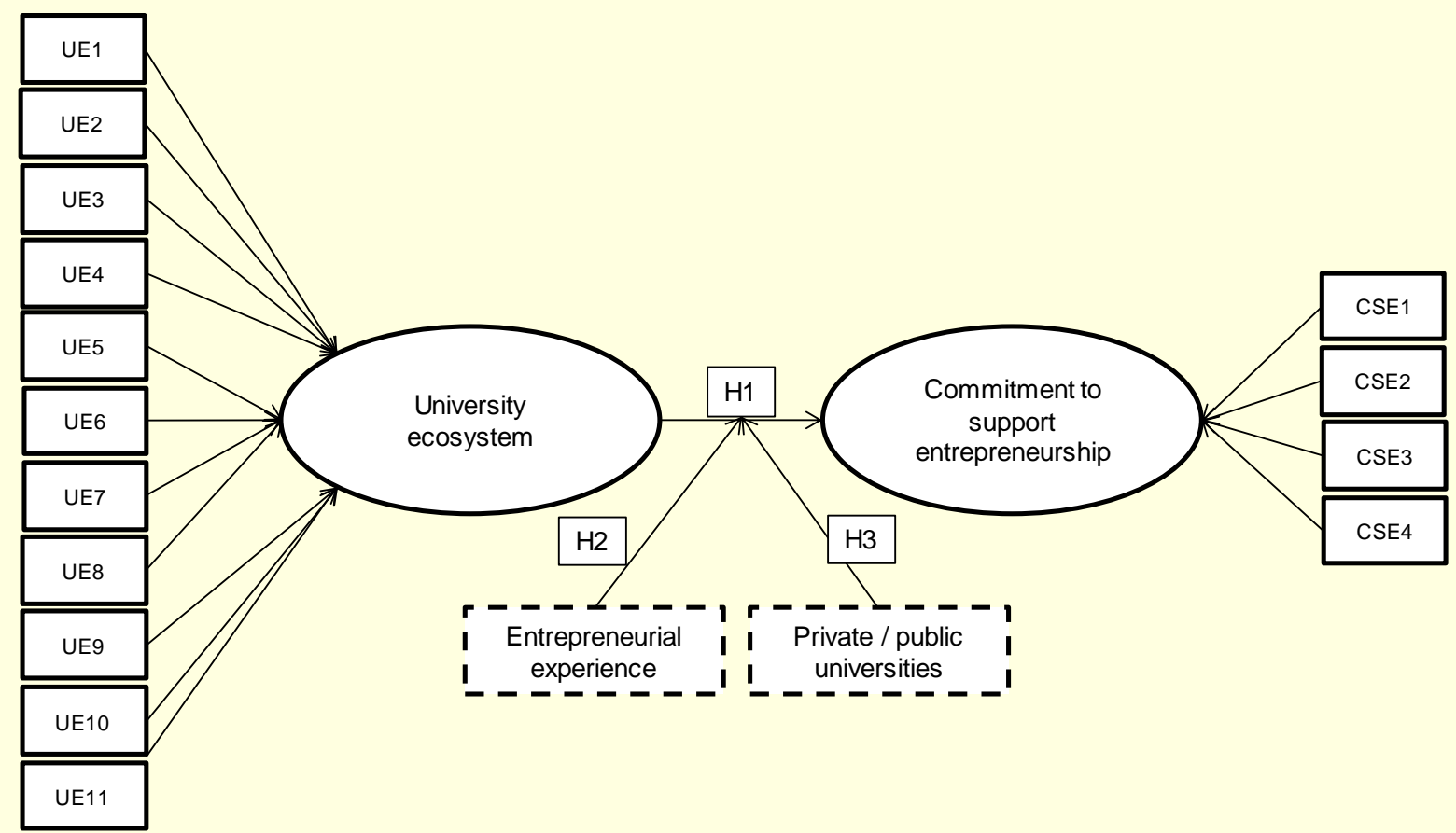

Figure 1. Conceptual model of research

The choice of indicators was based on the rationale provided in the literature review and which supports the research hypotheses. Therefore, our research has employed the term university ecosystem to define the many teaching, research, and entrepreneurial initiatives at the institutional level. Hence, UE\# variables stand for different aspects related to the university ecosystem as manifestations of formal organizational initiatives aiming at nurturing entrepreneurship as a strategic field within higher education institutions. Following the literature on intrapreneurship in academic settings, these elements comprehend internal and strategic assets associated to universities' approach to establish a corporate culture of entrepreneurship 
(Braunerhjelm, 2007; Dovey \& Rembach, 2015; Kirby, 2006; Markuerkiaga et al., 2014). The UE indicators are detailed in Table 1.

Table 1

\section{Scale indicators of the measuring instrument for university ecosystem}

\begin{tabular}{|c|c|}
\hline Indicator & Question $(\mathrm{Q})$ and answer options (A) \\
\hline \multirow[b]{2}{*}{ UE1 $1^{\mathrm{a}}$} & $\begin{array}{l}\text { (Q) Institutional partnership or support which the HEI receives from agencies/institutions in activities directly } \\
\text { related to entrepreneurship. }\end{array}$ \\
\hline & $\begin{array}{l}\text { (A) City hall; state government; federal government; national Sebrae; state Sebrae; local small and medium } \\
\text { enterprises; big companies; investment funds; local NGOs; national NGOs; international researchers; other } \\
\text { national HEls; funding agencies. }\end{array}$ \\
\hline \multirow[b]{2}{*}{ UE2 ${ }^{a}$} & $\begin{array}{l}\text { (Q) Institutional partnership or support offered by the } \mathrm{HEI} \text { to agencies/institutions in activities directly related to } \\
\text { entrepreneurship. }\end{array}$ \\
\hline & $\begin{array}{l}\text { (A) City hall; state government; federal government; national Sebrae; state Sebrae; local small and medium } \\
\text { enterprises; big companies; investment funds; local NGOs; national NGOs; international researchers; other } \\
\text { national HEls; funding agencies. }\end{array}$ \\
\hline \multirow[b]{2}{*}{$\mathrm{UE3}^{\mathrm{a}}$} & (Q) Existing structures within the $\mathrm{HEI}$ for elaborating and providing content on entrepreneurship. \\
\hline & $\begin{array}{l}\text { (A) Entrepreneurship center; entrepreneurship and small business department; technological innovation } \\
\text { center; faculty of business/administration. }\end{array}$ \\
\hline \multirow[b]{2}{*}{ UE4 ${ }^{\text {a }}$} & (Q) Opportunities related to entrepreneurship which are offered by the $\mathrm{HEI}$. \\
\hline & $\begin{array}{l}\text { (A) Internship opportunities in: start up; micro and small businesses; medium enterprises; large companies; } \\
\text { public sector; third sector. }\end{array}$ \\
\hline \multirow[b]{2}{*}{ UE5 $^{\mathrm{a}}$} & (Q) Entrepreneurship related research activities offered by the HEI. \\
\hline & $\begin{array}{l}\text { (A) Minor in entrepreneurship; research on entrepreneur behavior; research on HEl's own entrepreneurial } \\
\text { ecosystem; research on entrepreneur ecosystem as a whole; available teacher for studies or innovation and } \\
\text { technology creation; teacher involved in entrepreneurship research; entrepreneurship research group; } \\
\text { research centers available for entrepreneur case study. }\end{array}$ \\
\hline \multirow[b]{2}{*}{ UE6 $^{\text {a }}$} & (Q) Entrepreneurship related events offered by the $\mathrm{HEI}$. \\
\hline & $\begin{array}{l}\text { (A) Global entrepreneurship week; innovation fair; entrepreneurship fair; visits and excursions focused on } \\
\text { entrepreneurship; hackatons or startup weekend; speakers invited to talk about entrepreneurship; pitch } \\
\text { competition. }\end{array}$ \\
\hline \multirow[b]{2}{*}{ UE7 ${ }^{\text {a }}$} & (Q) Entrepreneurship related programs offered by the HEI. \\
\hline & $\begin{array}{l}\text { (A) Entrepreneurship education collaboration program for elementary and high schools; endeavor program; } \\
\text { incubator / accelerator; technologic park; alumni program; student organizations focused on small business; } \\
\text { student business support services; maker spaces/fablabs; entrepreneurship mentorships; entrepreneurship } \\
\text { scholarship program; national and international competitions related to entrepreneurship; investor contact } \\
\text { network; entrepreneurship laboratory. }\end{array}$ \\
\hline \multirow[b]{2}{*}{ UE8 ${ }^{a}$} & (Q) Entrepreneurship related subjects offered by the HEI in different educational levels. \\
\hline & $\begin{array}{l}\text { (A) Undergraduate course; postgraduate course; executive education; MBA; master's degree; doctorate } \\
\text { degree; continuing education; distance education. }\end{array}$ \\
\hline \multirow{2}{*}{ UE9 } & (Q) Evaluation of the quantity of entrepreneurship related subjects offered by the HEI. \\
\hline & (A) Likert scale ranging from "1: totally dissatisfied" to "5: totally satisfied". \\
\hline \multirow{2}{*}{ UE10 } & (Q) Evaluation of the quality of entrepreneurship related subjects offered by the HEI. \\
\hline & (A) Likert scale ranging from "1: totally dissatisfied" to "5: totally satisfied". \\
\hline & (Q) Educational strategies employed in entrepreneurship related disciplines offered by the HEI. \\
\hline UE11 a & $\begin{array}{l}\text { (A) Interdisciplinarity; self-learning activities; strategic vision activities; case studies of successful } \\
\text { entrepreneurs; brainstorming; business plan / canvas development; written assignments; written tests; student } \\
\text { assessment of subjects. }\end{array}$ \\
\hline
\end{tabular}

Note. a Respondents had to answer "yes," "no," or "I don't know" and at each option marked "yes" the indicator added one point.

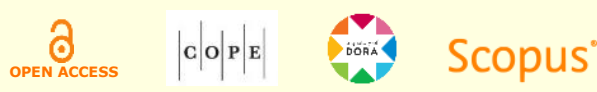


In its turn, CSE\# indicators approximate faculty engagement with the promotion of entrepreneurship within the institution, i.e., individual-level commitment to setting an entrepreneurial culture. Although these dependent indicators are limited to entrepreneurial education, they provide an insightful perspective on how faculty members promote entrepreneurial thinking among participants of the academic community, a key aspect of establishing an entrepreneurial university (Clark, 1998; Kirby, 2006; Markuerkiaga et al., 2014; Rae et al., 2009; Rao \& Mulloth, 2017). The CSE indicator is detailed in Table 2.

Table 2

Scale indicators of the measuring instrument for commitment to support entrepreneurship

\begin{tabular}{ll}
\hline Indicator & Question (Q) and answer options (A) \\
CSE1 & (Q) Position related to entrepreneurship within the institution. \\
& $\begin{array}{l}\text { (A) There were four positions options: (1) teacher of another course / discipline; (2) coordinator of another } \\
\text { course / discipline; (3) entrepreneurship teacher; (4) entrepreneurship coordinator. }\end{array}$ \\
CSE2 & $\begin{array}{l}\text { (Q) Relation to the promotion of entrepreneurship in the HEI. } \\
\text { (A) There were four options: (1) a person without much contact with the entrepreneurship actions at HEI; (2) a } \\
\text { supporter of entrepreneurship actions in HEl; (3) an active contributor to entrepreneurship promotion in HEI; } \\
\text { (4) HEI entrepreneurship promotion leadership. }\end{array}$ \\
CSE3 a & $\begin{array}{l}\text { (Q) Types of undertaken entrepreneurship related training. } \\
\text { (A) Graduation; Master; PhD; MBA; training offered specifically to your HEI teachers; Endeavor empowerment; }\end{array}$ \\
\hline extension programs.
\end{tabular}

Note. "Respondents had to answer "yes," "no," or "I don't know" and at each option marked "yes" the indicator added one point.

The moderator question of faculty entrepreneurial experience had four answer options: (a) No, I don't want/I don't have time; (b) No, but I still want it; (c) Yes, but not currently; (d) Yes, until today. This ordinal structure is used as a moderator in our model comprehending different shades of the entrepreneurial event embedded in faculty members. In its turn, the multigroup analysis question regarding the institution where the faculty worked had two options: (a) public; (b) private.

Data was collected by Endeavor Brazil in partnership with the Brazilian Micro and Small Business Support Service (Sebrae) and the Data Popular Institute and made available for the purposes of the present research. Data covers 680 faculty from over 70 higher education institutions (HEIs) located across 22 Brazilian states. Interviews were conducted between April and May 2016 and were held through the application of the intercept research methodology (randomly selected faceto-face interviews) and computer assisted telephone interviewing (Endeavor, 2017). This dataset provides a representative sample of university professors in the country with a $95 \%$ confidence interval. The information collected offers a comprehensive set of variables that allow an exploratory assessment of the role played by the university ecosystem in shaping the engagement of faculty members in supporting entrepreneurial activities.

The final sample of 680 faculty members had a mean age of 44 years, $58 \%$ male, $39 \%$ public university faculty and $35 \%$ with a $\mathrm{PhD}$ degree. Of this total, $19 \%$ had their own business and

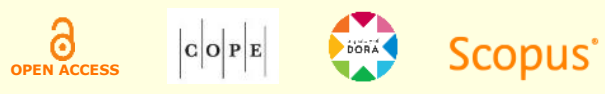


another $18 \%$ had already had previously owned businesses. Entrepreneurial rates in the sample seem to reproduce the patterns presented for the country according to the Global Entrepreneurship Monitor report (Kelley, Singer, \& Herrington, 2016). About 30\% of faculty evaluated themselves as active leaders and contributors in promoting entrepreneurship at their university. However, only $47.6 \%$ of these active leaders teach an entrepreneurship discipline.

This result illustrates that often the entrepreneurship faculty is not the protagonist of the entrepreneurial education in their institution, especially in universities with no structure for this purpose or with initiatives restricted to certain courses, such as administration and engineering (Endeavor, 2017). Missing values did not exceed 10\% and there was no high proportion of missing responses for each single construct. Thus, no responses needed to be deleted from the database (following Hair, Hult, Ringle, \& Sarstedt, 2017).

To evaluate the sample size and statistical power of the analyses we used the $\mathrm{G}^{*}$ Power 3.1 software (Faul, Erdfelder, Buchner, \& Lang, 2009), according to recommendations by Chin and Newsted (1999), Cohen (1988), and Hair et al. (2017). The largest number of predictors of a latent variable is 11 , therefore presenting significance level of $5 \%$, statistical power of 0.8 , and average effect size $\left(f^{2}=0.15\right.$, which is equivalent to $r^{2}=13 \%$ ). In terms of sample size, the required minimum was 123 observations. However, the final sample used comprehended 680 observations, thus making the model suitable for estimation by PLS-SEM. Post hoc analyses for the acquired sample indicate that: (a) any $\mathrm{r}^{2}$ higher than $2.44 \%$ would be significant, retaining the power of 0.8 and the significance level of $5 \%$; and (b) for the average effect size, the power is 0.999 , which is above 0.8 , the recommended threshold by Chin and Newsted (1999) and Hair et al. (2017). For calculations and validations of the statistical tests, we used SmartPLS 3.0 software (Ringle, Wende, \& Becker, 2015).

\section{Findings}

The research model has only formative indicators (university ecosystem and commitment to support entrepreneurship), and the criteria for evaluation of formative measurement models are: convergent validity, multicollinearity analysis, and significance and relevance (Hair et al., 2017). Redundancy analysis determined convergent validity. This was achieved through the correlation of variables of the formative construct with a global measure of the indicator. The construct was modeled as the independent variable and the global measure as the dependent variable. It is necessary that the path coefficient value reach levels above 0.80 so that the formative construct has convergent validity (Hair et al., 2017). In the case of the university ecosystem construct, the value was of 0.863 , and for commitment to support entrepreneurship, the value was 0.813 , thus providing support for convergent validity. To test the collinearity of indicators, the values of Variance Inflation Factor (VIF) for variables of the formative construct should be lower than five (Hair et al., 2017), and all values were within the established range.

In order to analyze significance and relevance, we used the bootstrapping technique. According to the t-statistics of outer weights, some indicators are non-significant. However, Hair et al. (2017) recommend analyzing the outer loadings as well. In the t-statistics analysis of the outer loadings,

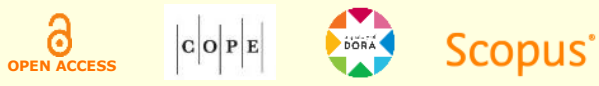


all variables are significant, thus the recommendation is to keep the variables in the analysis. In addition, before evaluating the structural model, it is necessary to evaluate its collinearity. The values of tolerance and VIF for each subpart of the model were analyzed for collinearity. Results are within those established by Hair et al. (2017), with tolerance being above 0.2 and VIF below 5 .

The bootstrapping technique was once again used to analyze the significance of indicators (Efron $\&$ Tibshirani, 1998). The use of this technique to analyze the significance of the acquired loadings for the observable variables is not only based on a model estimation, but also on a calculation of estimates of parameters and their confidence intervals based on multiple estimates (Hair et al., 2017). Student's t-test analyzes the hypothesis that coefficients of correlation are equal to zero. If the results of this test indicate values higher than 1.96, the null hypothesis is not accepted, and the correlation is significant (Efron \& Tibshirani, 1998; Hair et al., 2017). The value of the relationships presented Student t-values higher than 1.96 (significance level $=5 \%$ ), thus lending support to hypothesis 1 . Table 3 presents the values of coefficients between the constructs and their respective Student's t-tests. The values were also estimated by a bootstrapping technique.

Table 3

Coefficients of the structural model - between constructs

\begin{tabular}{ccccc}
\hline & Average & Std. Error & T-Value & P-Value \\
\hline $\begin{array}{c}\text { University Ecosystem } \rightarrow \text { Commitment to Support } \\
\text { Entrepreneurship }\end{array}$ & 0.852 & 0.013 & 63.04 & 0.00 \\
\hline
\end{tabular}

The assessment of the coefficient of determination $\left(\mathrm{r}^{2}\right)$ was based on studies by Cohen (1988) and Faul, Erdfelder, Buchner and Lang (2009), who determined that $f^{2}$ values equal to 0.02, 0.15, and 0.35 are considered, respectively, as small, medium, and large effects. The acquired $f^{2}$ values presented results of $\mathrm{r}^{2}$ equal to $2 \%, 13 \%$, and $25 \%$, respectively. According to the responses, the Commitment to Support Entrepreneurship construct presented an $r^{2}=0.714$, which can be considered high.

To test our second hypothesis (H2), i.e., if faculty entrepreneurial experience can moderate the impact of university ecosystem on the commitment to support entrepreneurial activities, the moderating effects were used, according to guidelines from Hair, Sarstedt, Ringle and Gudergan (2018). Table 4 presents the results from the moderating effects analysis.

Table 4

\section{Moderating effects analysis}

\begin{tabular}{ccc}
\hline Indicator & $\begin{array}{c}\text { Coefficient-UE } \\
\text { Entrepreneurial Experience }\end{array}$ & \begin{tabular}{c} 
P-Value Entrepreneurial $_{\text {Experience }}$ \\
\hline $\begin{array}{c}\text { University Ecosystem } \rightarrow \text { Commitment to Support } \\
\text { Entrepreneurship }\end{array}$
\end{tabular} \\
\hline
\end{tabular}

Results from Table 4 show that the higher the entrepreneurial experience of faculty, the more intense is the effect of universities ecosystems on the commitment to support entrepreneurial

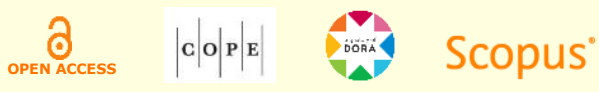


activities, thus confirming hypothesis 2 . The synthesis of the study's hypotheses tests (Table 5) was obtained with validations derived from the structural model.

To test our third hypothesis (H3), i.e., if private universities present stronger relationships between their academic ecosystems and the commitment of faculty members to support entrepreneurial activities, the multigroup analysis was used, according to guidelines from Hair et al. (2018). Table 5 presents the results from the multigroup analysis.

\section{Table 5}

\section{Multigroup analysis}

\begin{tabular}{ccc}
\hline Indicator & $\begin{array}{c}\text { Path Coefficients-difference } \\
\text { (Public vs. Private) }\end{array}$ & $\begin{array}{c}\text { P-Value } \\
\text { (Public vs. Private) }\end{array}$ \\
\hline $\begin{array}{c}\text { University Ecosystem } \rightarrow \text { Commitment to Support } \\
\text { Entrepreneurship }\end{array}$ & 0.011 & 0.646 \\
\hline
\end{tabular}

Results from Table 5 do not indicate a significant difference in the relationship between universities' ecosystems and the commitment of faculty to support entrepreneurial activities in relation to public and private universities, thus not confirming hypothesis 3 .

The synthesis of the study's hypotheses (Table 6) were obtained with validations derived from the structural model.

Table 6

Synthesis of the study's hypotheses test

\begin{tabular}{lll}
\hline Hypotheses & Description & Result \\
\hline $\mathrm{H} 1$ & $\begin{array}{l}\text { Entrepreneurship-friendly university ecosystems have a positive influence on the } \\
\text { commitment of faculty members to support entrepreneurial activities. }\end{array}$ & CONFIRMED \\
\hline $\mathrm{H} 2$ & $\begin{array}{l}\text { Entrepreneurial experience of faculty moderates the impact of universities' } \\
\text { ecosystems on the commitment of faculty to support entrepreneurial activities. }\end{array}$ & CONFIRMED \\
\hline H3 & $\begin{array}{l}\text { In a comparison with public institutions, private universities present stronger } \\
\text { relationships between their academic ecosystems and the commitment of faculty } \\
\text { members to support entrepreneurial activities. }\end{array}$ & NOT CONFIRMED \\
\hline
\end{tabular}

Figure 2 presents a detailed perspective of the end results of the quantitative analysis. 


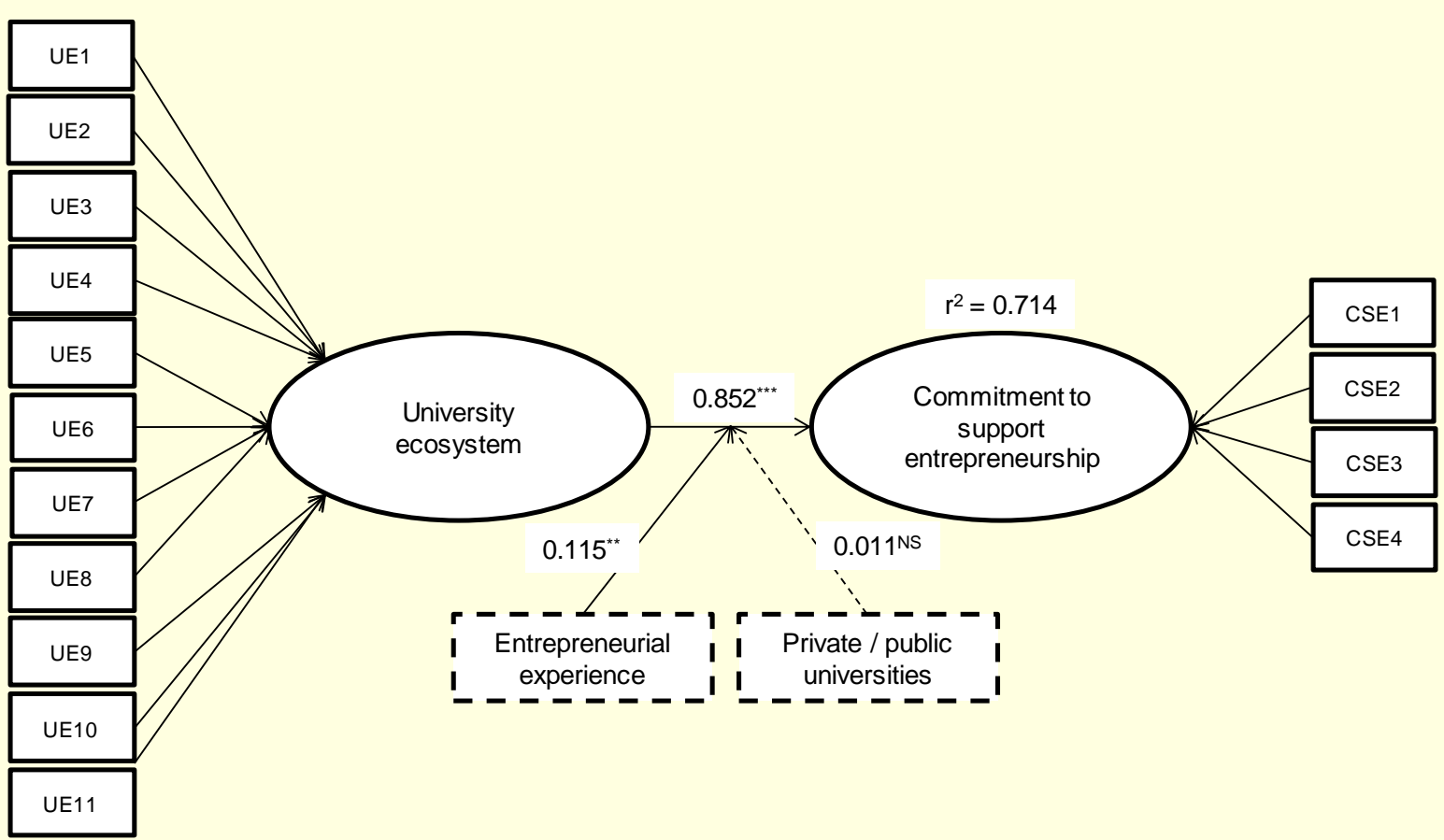

Figure 2. Resulting research model

${ }^{* \star \star}=$ significant at $0.1 \% ;{ }^{* *}=$ significant at $0.5 \% ;{ }^{*}=$ significant at $1 \% ; \mathrm{NS}=$ not significant

\section{Discussion}

This research was able to meet its goal of analyzing the influence of the university ecosystem on the commitment of faculty to support entrepreneurial activities by presenting a consistent model with high explanatory value of the latent variable: commitment to support entrepreneurship. In relation to the study's results, commitment to support entrepreneurship is positively influenced by more developed universities' ecosystems. This research sought to address entrepreneurial activity from a different perspective from the extant literature in the field - usually focused on direct effects of the university ecosystem on new venture creation. Our results demonstrate a positive relationship between institutional conditions related to entrepreneurship and the faculty's commitment to supporting entrepreneurial activities, thus offering novel insights on the dynamics of entrepreneurship within academic settings.

Drawing from these empirical findings, some further discussions are due. First, we assess the fact that the outcomes of institutional and cultural changes can alter the patterns of student learning and their respective entrepreneurial behavior (Mars \& Rios-Aguilar, 2010). Moreover, entrepreneurial culture at the level of universities is a complex and cumulative phenomenon that relies on developments that evolve over long periods of time (Wadhwani et al., 2017).

In this regard, looking at the effectiveness of entrepreneurship-oriented initiatives within a shortterm horizon might offer misguided conclusions. For instance, while recent research has failed to identify a clear relationship between activities targeting student entrepreneurship (Alves et al., 2019; Endeavor, 2017), it might be the case that such doings move in a slower pace than

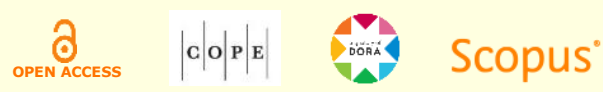


anticipated. Altering the faculty behavior can render a positive evolution of entrepreneurship in students - but in the long-term.

Hence, bearing in mind the fundamental role played by the faculty as educational leaders (Birdthistle, Hynes, \& Fleming, 2007; Deakins, Glancey, Menter, \& Wyper, 2005; Montecinos, Walker, \& Maldonado, 2015; Tuytens \& Devos, 2011), these findings emphasize that investing in institutional conditions related to entrepreneurship can have significant effects on the entrepreneurial culture of HEIs. This is in line with arguments concerning intrapreneurial behavior in academia, where the generation of a solid entrepreneurial climate is a key antecedent of entrepreneurial behavior (Van der Sijde \& Van Tilburg, 1998). In this regard, understanding the dynamics that shape faculty members' leadership offers valuable insights for researchers and practitioners, provided that these individuals have significant impacts in setting the stage for entrepreneurial universities to emerge (Farrukh et al., 2019; Huyghe \& Knockaert, 2015; Rae et al., 2009).

As per our findings, novel ways to shape the university ecosystem are likely to be more effective. These include developing institutional partnerships directly linked to entrepreneurship (e.g.: town halls, the government, business associations, small and medium sized local companies, big sized companies, NGOs, and other universities). In a similar vein, creating intrapreneurial approaches for elaborating and providing content on entrepreneurship can be a functional alternative. These involve, for instance, entrepreneurial centers and departments, small business ventures, technological innovation hubs, and integration of business schools with other fields of knowledge within the institution.

Secondly, the inclusion of entrepreneurship as a field of research can represent an important step forward in shaping institutional conditions for an entrepreneurial culture to flourish. This involves also approximating researchers and students to events related to entrepreneurship inside the university, such as global entrepreneurship week, innovation fairs, entrepreneurship fairs, business idea competitions, hackatons, startup weekends, lectures, and pitch competitions. Such initiatives can also lead to mentoring and networking activities not only within academia, but also connecting universities and markets.

Complementarily, the entrepreneurial experience of faculty members is a relevant moderator to be considered in setting the stage for thriving universities' ecosystems. These individuals can facilitate connections between academia and the business environment while also conveying their practical knowledge to students. Since professors with a stronger entrepreneurial background are also more engaged with promoting an entrepreneurial culture, such profiles should be considered in recruitment processes (Freel et al., 2019).

These suggestions are in line with the variables used to compose the university ecosystem construct and have presented substantial statistical significance respective to the relationship proposed in the theoretical model. In this regard, our results complement other studies that mention the lack of an adequate configuration in universities to potentialize entrepreneurs, be it in students or faculty (Ács et al., 2009; Bercovitz \& Feldman, 2004; Huyghe \& Knockaert, 2015).

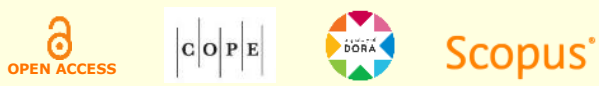


Somewhat surprisingly, results do not indicate any difference in the intrapreneurial dynamics addressed in our empirical exercise. Both theoretical and empirical arguments assessed generated expectations that private universities - with more organizational flexibility and capacity to establish innovative reward systems - would present a stronger relationship between ecosystemic features and faculty commitment towards entrepreneurship. Nonetheless, as recently stressed by the Entrepreneurial Universities Report (Brasil Júnior, 2019), public universities in Brazil are actually leaders in entrepreneurial orientation. This can be taken as an indication that the evaluation of corporate entrepreneurship in both public and private academic institutions in Brazil is embedded in similar organizational contexts - contrary to common beliefs.

Unfortunately, "trends in hiring more administrators and non-teaching staff and having less fulltime faculty, present challenges for higher education to fulfill their new mandates" (Rubens et al., 2017, p. 364). This situation can represent a significant shortcoming in further engagement of educators in helping to establish an entrepreneurial culture in higher education institutions, although it might be overcome by individual and organizational initiatives to establish higher levels of university-industry interactions. In this regard, Technology Transfer Offices can have a strategic role in fostering market-oriented mindsets in faculty members. Nonetheless, most institutions still sustain reward systems and frameworks of incentives that are concentrated in publications and academic research activities (Benneworth, Pinheiro, \& Karlsen, 2017). We do not mean to downplay these structures, but it is highly doubtful that they shall enhance an organizational culture conducive to entrepreneurship. In any case, further inquiries on these issues represent promising avenues for future research on the dynamics of entrepreneurial universities.

\section{Final Remarks}

Although the entrepreneurial university concept has been around for a while (Etzkowitz, Webster, Gebhardt, \& Terra, 2000), fundamental gaps persist in our comprehension regarding the effectiveness of universities' strategies to further promote entrepreneurship. In this article, we sought to contribute to this debate by approaching the association between the organizational ecosystem and faculty behavior in driving intrapreneurial change in Brazilian universities. Such assessment is in line with existing propositions that establish that an effective institutional framework functions as an antecedent of market orientation in academia (Manning, 2018).

Empirical findings highlight the importance of nurturing institutional conditions related to entrepreneurship. Notwithstanding, universities in Brazil currently do not have adequate frameworks to support the journey of the entrepreneur (Endeavor, 2017). Incubators, entrepreneurial centers, access to investors, events, and other forms of support are still somewhat incipient within universities. Another matter of concern is the lack of strategic orientation and institutionalization of an entrepreneurial culture in Brazilian Higher Education Institutions.

Data from Brazil add to the body of research, which also mentions the lack of an adequate configuration in universities for supporting entrepreneurial behavior (Ács et al., 2009; Bercovitz

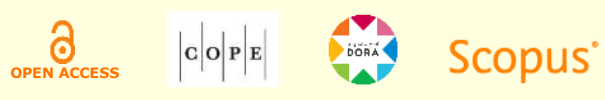


\& Feldman, 2004; Huyghe \& Knockaert, 2015). The Endeavor report also points to the fact that many students have difficulty seeing the faculty as a focal point for their doubts and needs regarding entrepreneurial activities, a probable consequence of the lack of dialogue between the university and its students (Endeavor, 2017). This information complements the outcomes of the present research, since the lack of institutional conditions oriented towards entrepreneurship reflects in a faculty board that falls short in developing the necessary set of skills to foster an entrepreneurial mindset in students, ultimately making them less engaged in nurturing entrepreneurship. Hence, from a practical standpoint, by focusing on the faculty, it is possible to identify more effective and systematic ways of promoting the implementation of more efficient intrapreneurial initiatives in universities, as well as the creation of an entrepreneurial culture.

In sum, our findings emphasize the relevance of establishing critical assessments on the complexity of academic initiatives that aim at promoting higher levels of entrepreneurial activity. As research limitations, we underscore the scope of the questions in the secondary database, which stand for a limited perspective of the university ecosystem and the commitment of the faculty (mainly attached to educational practices). The cross-section nature of data also hinders our analysis to understand how the association between variables of interest evolves over time. Thus, our results call for further research looking into longer timeframes, also checking more closely the determinants of corporate entrepreneurship leading to the implementation of entrepreneurial universities in different ways. In addition, we see good prospects for qualitative work that can offer in-depth perspectives on the issues at play when it comes to analyzing the role of faculty members in building an entrepreneurial culture in academic institutions.

\section{Acknowledgments}

Authors acknowledge the database provided by Endeavor Brazil and Brazilian Micro and Small Business Support Service (Sebrae). Bruno Fischer's contribution to this article is based on the study funded by the Basic Research Program of the National Research University Higher School of Economics (HSE) and by the Russian Academic Excellence Project "5-100". Bruno Fischer and Paola Schaeffer acknowledge funding from the São Paulo Research Foundation (Fapesp Grant \#2016/17801-4). The usual disclaimer applies.

\section{References}

Abaho, E., Olomi, D. R., \& Urassa, G. C. (2015). Students' entrepreneurial self-efficacy: Does the teaching method matter? Education + Training, 57(8/9), 908-923. https://doi.org/10.1108/et-02-2014-0008

Abreu, M., \& Grinevich, V. (2013). The nature of academic entrepreneurship in the UK: Widening the focus on entrepreneurial activities. Research Policy, 42(2), 408-422. https://doi.org/10.1016/j.respol.2012.10.005

Ács, Z., Braunerhjelm, J., Audretsch, D., \& Carlsson, B. (2009). The knowledge spillover theory of entrepreneurship. Small Business Economics, 32(1), 15-30. https://doi.org/10.1007/s11187-008-9157-3

Alves, A., Fischer, B., Schaeffer, P., \& Queiroz, S. (2019). Determinants of student entrepreneurship: An assessment on higher education institutions in Brazil. Innovation $\mathcal{E}$ Management Review, 16(2), 96-117. https://doi.org/10.1108/inmr-02-2018-0002

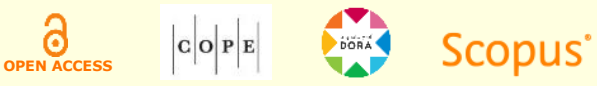


Andrade, J. A. (2012). Universidades empreendedoras e o contexto do nordeste brasileiro. Revista Gestão $\mathfrak{E}$ Tecnologia, 12(2), 4-32. http://dx.doi.org/10.20397/2177-6652/2012.v12i2.368

Audretsch, D. B. (2007). Entrepreneurship capital and economic growth. Oxford Review of Economic Policy, 23(1), 63. 78. https://doi.org/10.1093/oxrep/grm001

Audretsch, D. B., Grilo, I., \& Thurik, A. R. (2011). Globalization, entrepreneurship, and the region. In M. Fritsch (Ed.), Handbook of research on entrepreneurship (pp. 11-32). Cheltenham, UK: Edward Elgar.

Barral, M. R. M., Ribeiro, F. G., \& Canever, M. D. (2018). Influence of the university environment in the entrepreneurial intention in public and private universities. RAUSP Management Journal, 53(1), 122-133. https://doi.org/10.1016/j.rauspm.2017.12.009

Belitski, M., \& Heron, K. (2017). Expanding entrepreneurship education ecosystems. Journal of Management Development, 36(2), 163-177. https://doi.org/10.1108/jmd-06-2016-0121

Bennett, R. (2006). Business lecturers' perceptions of the nature of entrepreneurship. International Journal of Entrepreneurial Behavior Eु Research, 12(3), 165-188. https://doi.org/10.1108/13552550610667440

Benneworth, P., Pinheiro, R., \& Karlsen, J. (2017). Strategic agency and institutional change: Investigating the role of universities in regional innovation systems (RISs). Regional Studies, 51(2), 235-248. https://doi.org/10.1080/00343404.2016.1215599

Bercovitz, J., \& Feldman, M. (2004). Academic entrepreneurs: Social learning and participation in university technology transfer [Mimeo]. Toronto, Canada: University of Toronto.

Bercovitz, J., \& Feldman, M. (2006). Entrepreneurial universities and technology transfer: A conceptual framework for understanding knowledge-based economic development. The Journal of Technology Transfer, 31(1), 175-188. https://doi.org/10.1007/s10961-005-5029-z

Bercovitz, J., \& Feldman, M. (2008). Academic entrepreneurs: organizational change at the individual level. Organization Science, 19(1), 69-89. https://doi.org/10.1287/orsc. 1070.0295

Beyhan, B., \& Findik, D. (2018). Student and graduate entrepreneurship: Ambidextrous universities create more nascent entrepreneurs. Journal of Technology Transfer, 43(5), 1346-1374. https://doi.org/10.1007/s10961-0179590-z

Bienkowska, D., \& Klofsten, M. (2012). Creating entrepreneurial networks: Academic entrepreneurship, mobility and collaboration during PhD education. Higher Education, 64(2), 207-222. https://doi.org/10.1007/s10734011-9488-x

Bienkowska, D., Klofsten, M., \& Rasmussen, E. (2016). PhD students in the entrepreneurial university - Perceived support for academic entrepreneurship. European Journal of Education, 51(1), 56-72. https://doi.org/10.1111/ejed.12160

Birdthistle, N., Hynes, B., \& Fleming, P. (2007). Enterprise education programmes in secondary schools in Ireland: A multi-stakeholder perspective. Education + Learning, 265-276. https://doi.org/10.1108/00400910710754426

Boh, W. F., De-Haan, U., \& Strom, R. (2016). University technology transfer through entrepreneurship: Faculty and students in spinoffs. The Journal of Technology Transfer, 41(4), 661-669. https://doi.org/10.1007/s10961-0159399-6

Brasil Júnior. (2019). Universidades empreendedoras 2019. Retrieved from https://universidadesempreendedoras.org/wp-content/uploads/2019/10/ranking-2019.pdf

Braunerhjelm, P. (2007). Academic entrepreneurship: Social norms, university culture and policies. Science and Public Policy, 34(9), 619-631. https://doi.org/10.3152/030234207×276554

Brennan, M.C., Wall, A.P., \& McGowan, P. (2005). Academic entrepreneurship: assessing preferences in nascent entrepreneurs. Journal of Small Business and Enterprise Development, 12(3), 307-322. https://doi.org/10.1108/14626000510612240

Canever, M. D., Barral, M. R. M., \& Ribeiro, F. G. (2017). How does the public and private university environment affect students' entrepreneurial intention? Education + Training, 59(6), 550-564. https://doi.org/10.1108/et-12. 2016-0187

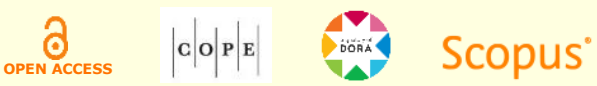


Chiles, T. H., Bluedorn, A. C., \& Gupta, V. K. (2007). Beyond creative destruction and entrepreneurial discovery: A radical Austrian approach to entrepreneurship. Organization Studies, 28(4), 467-493. https://doi.org/10.1177/0170840606067996

Chin, W. W., \& Newsted, P. R. (1999). Structural equation modeling analysis with small samples using partial least squares. In R. H. Hoyle (Ed.), Statistical strategies for small sample research (pp. 307-341). Thousand Oaks, CA: Sage Publications.

Clark, B.R. (1998). Creating entrepreneurial universities: Organisational pathways to transformation. Oxford, UK: Pergamon Press.

Cohen, J. (1988). Statistical power analysis for the behavioral sciences (2nd ed.). Hillsdale, MI: Erlbaum.

Coyle, P. (2014). How entrepreneurial leadership can engage university staff in the development of an entrepreneurial culture. Industry and Higher Education, 28(4), 263-269. https://doi.org/10.5367/ihe.2014.0215

Deakins, D., Glancey, K., Menter, I., \& Wyper, J. (2005). Enterprise education: The role of head teachers. The International Entrepreneurship and Management Journal, 1(2), 241-263. https://doi.org/10.1007/s11365-005-1131-9

Diegoli, R. B., Gutierrez, H. S. M., \& Salmones, M. M. G. (2018). Teachers as entrepreneurial role models: The impact of teacher's entrepreneurial experience and student learning styles in entrepreneurial intentions. Journal of Entrepreneurship Education, 21(1), 1-11. Retrieved from https://www.abacademies.org/articles/Teachers-asentrepreneurial-role-models-1528-2651-21-1-138.pdf

Dietz, J. S., \& Bozeman, B. (2005). Academic careers, patents, and productivity: Industry experience as scientific and technical human capital. Research Policy, 34(3), 349-367. https://doi.org/10.1016/j.respol.2005.01.008

Di Gregorio, D., \& Shane, S. (2003). Why do some universities generate more start-ups than others? Research Policy, 32(2), 209-227. https://doi.org/10.1016/s0048-7333(02)00097-5

Dovey, K., \& Rembach, M. (2015). Invisible practices; innovative outcomes: Intrapreneurship within the academy. Action Learning: Research and Practice, 12(3), 276-292. https://doi.org/10.1080/14767333.2015.1074885

Efron, B., \& Tibshirani, R. J. (1998). An introduction to the bootstrap. Boca Raton, FL: Chapman \& Hall / CRC Press.

Endeavor. (2017). Pesquisa empreendedorismo nas universidades brasileiras 2016. Retrieved from http://info.endeavor.org.br/eub2016

Etzkowitz, H. (1983). Entrepreneurial scientists and entrepreneurial universities in American academic science. Minerva, 21(2-3), 198-233. https://doi.org/10.1007/bf01097964

Etzkowitz, H., \& Leydesdorff, L. (2000). The dynamics of innovation: From national systems and 'Mode 2' to a triple helix of university. Research Policy, 29(2), 109-123. https://doi.org/10.1016/s0048-7333(99)00055-4

Etzkowitz, H., Webster, A., Gebhardt, C., \& Terra, B. R. C. (2000). The future of the university and the university of the future: Evolution of ivory tower to entrepreneurial paradigm. Research Policy, 29(2), 313-330. https://doi.org/10.1016/s0048-7333(99)00069-4

Farrukh, M., Lee, J. W. C., \& Shahzad, I. A. (2019). Intrapreneurial behavior in higher education institutes of Pakistan: The role of leadership styles and psychological empowerment. Journal of Applied Research in Higher Education, 11(2), 273-294. https://doi.org/10.1108/jarhe-05-2018-0084

Faul, F., Erdfelder, E., Buchner, A., \& Lang, A.-G. (2009). Statistical power analyses using G*Power 3.1: Tests for correlation and regression analyses. Behavior Research Methods, 41(4), 1149-1160. https://doi.org/10.3758/brm.41.4.1149

Fayolle, A., \& Liñán, F. (2014). The future of research on entrepreneurial intentions. Journal of Business Research, 67(5), 663-666. https://doi.org/10.1016/j.jbusres.2013.11.024

Feldman, B. D. (2014). Dissonance in the academy: The formation of the faculty entrepreneur. International Journal of Entrepreneurial Behaviour Eु Research, 20(5), 453-477. https://doi.org/10.1108/ijebr-08-2013-0124

Ferreira, J., Fayolle, A., Fernandes, C., \& Raposo, M. (2017). Effects of Schumpeterian and Kirznerian entrepreneurship on economic growth: Panel data evidence. Entrepreneurship and Regional Development, 29(1-2), 27-50. https://doi.org/10.1080/08985626.2016.1255431

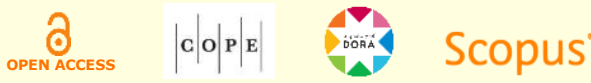


Fischer, B. B., Moraes, G. H. S. M., \& Schaeffer, P. R. (2019). Universities' institutional settings and academic entrepreneurship: Notes from a developing country. Technological Forecasting and Social Change, 147, 243-252. https://doi.org/10.1016/j.techfore.2019.07.009

Freel, M., Persaud, A., \& Chamberlin, (2019). Faculty ideals and universities' third mission. Technological Forecasting and Social Change, 147, 10-21. https://doi.org/10.1016/j.techfore.2019.06.019

Galambos, L., \& Amatori, F. (2016). The entrepreneurial multiplier effect. Enterprise $\mathscr{E}$ Society, 17(4), $763-808$. https://doi.org/10.1017/eso.2016.41

Galán-Muros, V., Sijde, P. van der, Groenewegen, P., \& Baaken, T. (2017). Nurture over nature: How do European universities support their collaboration with business? The Journal of Technology Transfer, 42(1), 184-205. https://doi.org/10.1007/s10961-015-9451-6

Gnyawali, D. R., \& Fogel, D. S. (1994). Environments for entrepreneurship development: Key dimensions and research implications. Entrepreneurship Theory and Practice, 18(4), 43-62. https://doi.org/10.1177/104225879401800403

Göktepe-Hultén, D. (2008). Academic inventors and research groups: Entrepreneurial cultures at universities. Science and Public Policy, 35(9), 657-667. https://doi.org/10.3152/030234208x363196

Goldstein, H. (2010). The 'entrepreneurial turn' and regional economic development mission of universities. The Annals of Regional Science, 44(1), 83-109. https://doi.org/10.1007/s00168-008-0241-z

Guerrero, M., \& Urbano, D. (2012). The development of an entrepreneurial university. Journal of Technology Transfer, 37(1), 43-74. https://doi.org/10.1007/s10961-010-9171-x

Guerrero, M., Urbano, D., \& Fayolle, A. (2016). Entrepreneurial activity and regional competitiveness: Evidence from European entrepreneurial universities. Journal of Technology Transfer, 41(1), 105-131. https://doi.org/10.1007/s10961-014-9377-4

Gulbrandsen, M., \& Thune, T. (2017). The effects of non-academic work experience on external interaction and research performance. Journal of Technology Transfer, 42(4), 795-813. https://doi.org/10.1007/s10961-017-9556-1

Gurãu, C., Dana, L.-P., \& Lasch, F. (2012). Academic entrepreneurship in UK biotechnology firms: Alternative models and the associated performance. Journal of Enterprising Communities: People and Places in the Global Economy, 6(2), 154-168. https://doi.org/10.1108/17506201211228958

Hair, J. F., Hult, G. T. M., Ringle, C. M., \& Sarstedt, M. (2017). A primer on partial least squares structural equation modeling (PLS-SEM). Thousand Oaks, CA: Sage.

Hair, J. F., Sarstedt, M., Ringle, C. M., \& Gudergan, S. P. (2018). Advanced issues in partial least squares structural equation modeling (PLS-SEM). Thousand Oaks, CA: Sage.

Hindle, K. (2007). Teaching entrepreneurship at university: From the wrong building to the right philosophy. In A. Fayolle (Ed.), Handbook of research in entrepreneurship education (pp. 104-126). Cheltenham, UK: Edward Elgar.

Hopkins, T., \& Feldman, H. (1989). Changing entrepreneurship education: Finding the right entrepreneur for the job. Journal of Organizational Change Management, 2(3), 28-40. https://doi.org/10.1108/09534818910145066

Huyghe, A., \& Knockaert, M. (2015). The influence of organizational culture and climate on entrepreneurial intentions among research scientists. Journal of Technology Transfer, 40(1), 138-160. https://doi.org/10.1007/s10961-014-9333-3

Ipiranga, A. S. R., Freitas, A. A. F., \& Paiva, D. (2010). O empreendedorismo acadêmico no contexto da interação universidade-empresa-governo. Cadernos EBAPE, 8(4), 676-693. https://doi.org/10.1590/s167939512010000400008

Ireland, R. D., Covin, J. G., \& Kuratko, D. F. (2009). Conceptualizing corporate entrepreneurship strategy. Entrepreneurship: Theory and Practice, 33(1), 19-46. https://doi.org/10.1111/j.1540-6520.2008.00279.x

Isenberg, D. (2010). How to start an entrepreneurial revolution. Harvard Business Review, 88(6), 40-51.

Kalar, B., \& Antoncic, B. (2015). The entrepreneurial university, academic activities and technology and knowledge transfer in four European countries. Technovation, 36-37, 11. https://doi.org/10.1016/j.technovation.2014.11.002

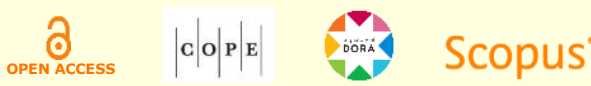


Kelley, D., Singer, S., \& Herrington, M. (2016). Global Entrepreneurship Monitor 2015/16 global report. London, UK: Global Entrepreneurship Research Association.

Kirby, D. (2006). Creating entrepreneurial universities in the UK: Applying entrepreneurship theory to practice. Journal of Technology Transfer, 31(5), 599-603. https://doi.org/10.1007/s10961-006-9061-4

Kirby, D., Urbano, D., \& Guerrero, M. (2011). Making universities more entrepreneurial: Development of a model. Canadian Journal of Administrative Sciences, 28(3), 302-316. https://doi.org/10.1002/cjas.220

Krueger, N. F., Reilly, M. D., \& Carsrud, A. L. (2000). Competing models of entrepreneurial intentions. Journal of Business Venturing, 15(5-6), 411-432. https://doi.org/10.1016/s0883-9026(98)00033-0

Lashley, C., \& Barron, P. (2006). The learning style preferences of hospitality and tourism students: Observations from an international and cross-cultural study. International Journal of Hospitality Management, 25(4), $552-569$. https://doi.org/10.1016/j.ijhm.2005.03.006

Liu, S. L., \& Dubinsky, A. J. (2000). Institutional entrepreneurship - A panacea for universities-in-transition. European Journal of Marketing, 34(11/12), 1315-1337. https://doi.org/10.1108/03090560010348470

Lubango, L. M., \& Pouris, A. (2007). Industry work experience and inventive capacity of South African academic researchers. Technovation, 27(12), 788-796. https://doi.org/10.1016/j.technovation.2007.05.013

Manning, L. (2018). Enabling entrepreneurial behaviour in a land-based university. Education + Training, 60(7-8), 735-748. https://doi.org/10.1108/et-03-2017-0036

Markuerkiaga, L., Errasti, N., \& Igartua, J. (2014). Success factors for managing an entrepreneurial university: Developing an integrative framework. Industry and Higher Education, 28(4), 233-244. https://doi.org/10.5367/ihe.2014.0214

Mars, M. M. (2007). The diverse agendas of faculty within an institutionalized model of entrepreneurship education. Journal of Entrepreneurship Education, 10, 43-62. Retrieved from https://www.abacademies.org/articles/jeevol102007.pdf

Mars, M.M., \& Rios-Aguilar, C. (2010). Academic entrepreneurship (re)defined: Significance and implications for the scholarship of higher education. Higher Education, 59(4), 441-460. https://doi.org/10.1007/s10734-009. 9258-1

Marzocchi, C., Kitagawa, F., \& Sánchez-Barrioluengo, M. (2019). Evolving missions and university entrepreneurship: academic spin-offs and graduate start-ups in the entrepreneurial society. Journal of Technology Transfer, 44(1), $167-$ 188. https://doi.org/10.1007/s10961-017-9619-3

Mason, C., \& Brown, R. (2014). Entrepreneurial ecosystems and growth-oriented entrepreneurship. Retrieved from https://www.oecd.org/cfe/leed/Entrepreneurial-ecosystems.pdf

Meyers, A., \& Pruthi, S. (2011). Academic entrepreneurship, entrepreneurial universities and biotechnology. Journal of Commercial Biotechnology, 17(4), 349-357. https://doi.org/10.1057/jcb.2011.22

Miller, D., \& Ács, Z. (2017). The campus as entrepreneurial ecosystem: The University of Chicago. Small Business Economics, 49(1), 75-95. https://doi.org/10.1007/s11187-017-9868-4

Montecinos, C., Walker, H., \& Maldonado, F. (2015). School administrators and university practicum supervisors as boundary brokers for initial teacher education in Chile. Teaching and Teacher Education, 49(1), 1-10. https://doi.org/10.1016/j.tate.2015.02.011

Moraes, G. H. S. M., Iizuka, E. S., \& Pedro, M. (2018). Effects of entrepreneurial characteristics and university environment on entrepreneurial intention. Revista de Administração Contemporânea, 22(2), 226-248. https://doi.org/10.1590/1982-7849rac2018170133

Morris, M., Shirokova, G., \& Tsukanova, T. (2017). Student entrepreneurship and the university ecosystem: A multicountry empirical exploration. European Journal of International Management, 11(1), 65-85. https://doi.org/10.1504/ejim.2017.10001679

Moutinho, P., Fontes, M., \& Godinho, M. (2007). Do individual factors matter? A survey of scientists' patenting in Portuguese public research organisations. Scientometrics, 70(2), 355-377. https://doi.org/10.1007/s11192-007$0207-4$

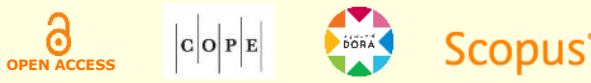


Nabi, G., Liñán, F., Fayolle, A., Krueger, N., \& Walmsley, A. (2017). The impact of entrepreneurship education in higher education: A systematic review and research agenda. Academy of Management Learning $\mathcal{E}$ Education, 16(2), 277-299. https://doi.org/10.5465/amle.2015.0026

Nasution, H. N., Mavondo, F. T., Matanda, M. J., \& Ndubisi, N. O. (2011). Entrepreneurship: Its relationship with market orientation and learning orientation and as antecedents to innovation and customer value. Industrial Marketing Management, 40(3), 336-345. https://doi.org/10.1016/j.indmarman.2010.08.002

Novotny, A. (2017). The heterogeneity of the academic profession: The effect of occupational variables on university scientists' participation in research commercialization. Minerva, 55(4), 485-508. https://doi.org/10.1007/s11024-017-9321-5

O’Shea, R., Allen, T., Morse, K., O'Gorman, C., \& Roche, F. (2007). Delineating the anatomy of an entrepreneurial university: The Massachusetts Institute of Technology experience. RED Management, 37(1), 1-16. https://doi.org/10.1111/j.1467-9310.2007.00454.x

Othman, N., Hashim, N., \& Wahid, H. (2012). Readiness towards entrepreneurship education: Students and Malaysian universities. Education + Training, 54(8-9), 697-708. https://doi.org/10.1108/00400911211274837

Perlatto, F. (2013). As mudanças estruturais das universidades públicas brasileiras: Uma proposta dialética de interpretação. Revista Pesquisa e Debate em Educação, 3(1), 13-27. Retrieved from http://www.revistappgp.caedufjf.net/index.php/revista1/article/view/45/35

Peterman, N., \& Kennedy, J. (2003). Enterprise education: Influencing students perceptions of entrepreneurship. Entrepreneurship: Theory and Practice, 28(2), 129-144. https://doi.org/10.1046/j.1540-6520.2003.00035.x

Piperopoulos, P. (2012). Could higher education programmes, culture and structure stifle the entrepreneurial intentions of students? Journal of Small Business and Enterprise Development, 19(3), 461-483. https://doi.org/10.1108/14626001211250162

Powers, J. B., \& McDougall, P. (2005). Policy orientation effects on performance with licensing to start-ups and small companies. Research Policy, 34(7), 1028-1042. https://doi.org/10.1016/j.respol.2005.05.014

Rae, D., Gee, S., \& Moon, R. (2009). Creating an enterprise culture in a university: The role of an entrepreneurial learning team. Industry and Higher Education, 23(3), 183-197. https://doi.org/10.5367/000000009788640279

Rao, B., \& Mulloth, B. (2017). The role of universities in encouraging growth of technology-based new ventures. International Journal of Innovation and Technology Management, 14(4), 1750014. https://doi.org/10.1142/s0219877017500146

Rasmussen, E., \& Borch, O. (2010). University capabilities in facilitating entrepreneurship: A longitudinal study of spin-off ventures at mid-range universities. Research Policy, 39(5), 601-612. https://doi.org/10.1016/j.respol.2010.02.002

Rasmussen, E., Moen, Ø., \& Gulbrandsen, M. (2006). Initiatives to promote commercialization of university knowledge. Technovation, 26(4), 518-533. https://doi.org/10.1016/j.technovation.2004.11.005

Rasmussen, E., Mosey, S., \& Wright, M. (2014). The influence of university departments on the evolution of entrepreneurial competencies in spin-off ventures. Research Policy, 43(1), 92-106. https://doi.org/10.1016/j.respol.2013.06.007

Rideout, E., \& Gray, D. (2013). Does entrepreneurship education really work? A review and methodological critique of the empirical literature on the effects of university-based entrepreneurship education. Journal of Small Business Management, 51(3), 329-351. https://doi.org/10.1111/jsbm.12021

Ringle, C. M., Wende, S., \& Becker, J. (2015). SmartPLS 3. [Software]. Bönningstedt, Germany: SmartPLS.

Rossano-Rivero, S., \& Wakkee, I. (2019). Academic entrepreneurship in the context of education: The role of the networking behaviour of academics. Journal of Science and Technology Policy Management, 10(4), 951-974. https://doi.org/10.1108/jstpm-03-2018-0034

Rowe, D. E. O., \& Bastos, A. V. B. (2010). Links between career and academic performance: Comparing teachers at private and public higher education establishments in Brazil. Revista de Administração Contemporânea, 14(6), 1011-1030. https://doi.org/10.1590/S1415-65552010000700003 
Rubens, A., Spigarelli, F., Cavicchi, A., \& Rinaldi, C. (2017). Universities' third mission and the entrepreneurial university and the challenges they bring to higher education institutions. Journal of Enterprising Communities: People and Places in the Global Economy, 11(3), 354-372. https://doi.org/10.1108/jec-01-2017-0006

Ruskovaara, E., Hämäläinen, M., \& Pihkala, T. (2016). HEAD teachers managing entrepreneurship education Empirical evidence from general education. Teaching and Teacher Education, 55, 155-164. https://doi.org/10.1016/j.tate.2016.01.004

Ruskovaara, E., Pihkala, T., Sikkula-Leino, J., \& Järvinen, M. R. (2015). Broadening the resource base for entrepreneurship education trough teachers' networking activities. Teaching and Teacher Education, 47, 62-70. https://doi.org/10.1016/j.tate.2014.12.008

Siegel, D., Waldman, D., \& Link, A. (2003). Assessing the impact of organizational practices on the relative productivity of university technology transfer offices: an exploratory study. Research Policy, 32(1), 27-48. https://doi.org/10.1016/s0048-7333(01)00196-2

Siegel, D., \& Wright, M. (2015). Academic entrepreneurship: Time for a re-think? British Journal of Management, 26(4), 582-595. https://doi.org/10.1111/1467-8551.12116

Speller, P., Robl, F., \& Meneghel, S. M. (2012). Desafios e perspectivas da educação superior brasileira para a próxima década. Brasília, Brazil: UNESCO, CNE, MEC.

Stadler, A., \& Smith, A. M. J. (2017). Entrepreneurship in vocational education: A case study of Brazilian context. Industry $\mathbb{E}$ Higher Education, 31(2), 81-89. https://doi.org/10.1177/0950422217693963

Tuytens, M., \& Devos, G. (2011). Stimulating professional learning through teacher evaluation: An impossible task for the school leader? Teaching and Teacher Education, 27(5), 891-899. https://doi.org/10.1016/j.tate.2011.02.004

Van der Sijde, P., \& Van Tilburg, J. (1998). Creating a climate for university spin-offs. Industry and Higher Education, 12(5), 297-302. https://doi.org/10.1177/095042229801200504

Vaziri, S. A., Safari, N., \& Akbarpur, S. A. (2013). Evaluation of behavioral factor and entrepreneurship organization in higher education. Life Science Journal, 10(5), 147-154.

Vorley, T., \& Nelles, J. (2010). Gone corporate? the changing face of entrepreneurship in contemporary universities. International Journal of Entrepreneurial Venturing, 2(2), 201-216. https://doi.org/10.1504/ijev.2010.034822

Wadhwani, R. D., Galvez-Behar, G., Mercelis, J., \& Guagnini, A. (2017). Academic entrepreneurship and institutional change in historical perspective. Management $\mathcal{E}$ Organizational History, 12(3), 175-198. https://doi.org/10.1080/17449359.2017.1359903

Whelan-Berry, K. S., Gordon, J., \& Hinings, C. (2003). Strengthening organizational change processes. Journal of Applied Behavioral Sciences, 39(2) 186-207. https://doi.org/10.1177\%2F0021886303256270

Woollard, D. (2010). Towards a theory of university entrepreneurship. Industry and Higher Education, 24(6), 413-427. https://doi.org/10.5367/ihe.2010.0017

\section{Author contributions}

$1^{\text {st }}$ author: conceptualization (equal), data curation (equal), formal analysis (equal), investigation (equal), methodology (lead), project administration (equal), resources (equal), software (equal), supervision (equal), validation (equal), visualization (equal), writing-original draft (equal), writing-review and editing (supporting).

$2^{\text {nd }}$ author: conceptualization (equal), data curation (equal), formal analysis (equal), investigation (equal), methodology (supporting), project administration (equal), resources (equal), software (equal), supervision (equal), validation (equal), visualization (equal), writing-original draft (equal), writing-review and editing (lead).

$3^{\text {rd }}$ author: conceptualization (equal), data curation (equal), formal analysis (equal), investigation (equal), methodology (supporting), project administration (equal), resources (equal), software (equal), supervision (equal), validation (equal), visualization (equal), writing-original draft (equal), writing-review and editing (supporting).

$4^{\text {th }}$ author: conceptualization (equal), data curation (equal), formal analysis (equal), investigation (equal), methodology (supporting), project administration (supporting), resources (equal), software (equal), supervision (equal), validation (equal), visualization (equal), writing-original draft (equal), writing-review and editing (supporting).

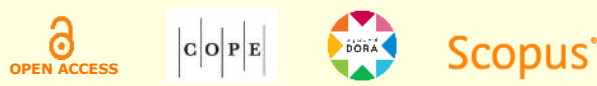




\section{Authors}

Gustavo Hermínio Salati Marcondes de Moraes

Universidade Estadual de Campinas, Faculdade de Ciências Aplicadas

Rua Pedro Zaccaria, 1300, 13083-872, Campinas, SP, Brazil

salati@unicamp.br

(iD) https://orcid.org/0000-0001-5238-0314

\section{Bruno Brandão Fischer}

Universidade Estadual de Campinas, Faculdade de Ciências Aplicadas

Rua Pedro Zaccaria, 1300, 13083-872, Campinas, SP, Brazil

bruno.fischer@fca.unicamp.br

(iD) https://orcid.org/0000-0003-3878-9097

\section{Matheus Leite Campos}

Universidade Estadual de Campinas, Faculdade de Ciências Aplicadas

Rua Pedro Zaccaria, 1300, 13083-872, Campinas, SP, Brazil

matheusleite_98@hotmail.com

(iD) https://orcid.org/0000-0001-6943-4948

\section{Paola Rücker Schaeffer}

Universidade Estadual de Campinas, Instituto de Geociências, Departamento de Política Científica e Tecnológica Rua Carlos Gomes, 250, 13083-855, Campinas, SP, Brazil

paolaschaeffer@ige.unicamp.br

(iD) https://orcid.org/0000-0002-0437-0987

Peer review is responsible for acknowledging an article's potential contribution to the frontiers of scholarly knowledge on business or public administration. The authors are the ultimate responsible for the consistency of the theoretical references, the accurate report of empirical data, the personal perspectives, and the use of copyrighted material. 